\title{
Chemistry, cytotoxicity and antileishmanial activity of the essential oil from Piper auritum
}

\author{
Lianet Monzote ${ }^{1 /+}$, Marley García ${ }^{1}$, Ana Margarita Montalvo', Ramón Scull², Migdalia Miranda² \\ 'Departamento de Parasitología, Instituto de Medicina Tropical Pedro Kourí, Apartado Postal 601, Marianao 13, Ciudad de la Habana, \\ Cuba ${ }^{2}$ Departamento de Química, Instituto de Farmacia y Alimentos, Universidad de la Habana, Ciudad de la Habana, Cuba
}

Leishmaniasis is one of the most important parasitic infections, but current treatments are unsatisfactory due to their toxicity, cost and resistance. Therefore, the development of new antileishmanial compounds is imperative. Many people who live in endemic areas use plants as an alternative to treat the disease. In this paper, we characterised the essential oil from Piper auritum, evaluated its cytotoxicity and determined its antileishmanial activity. The chromatogram obtained by gas chromatography revealed 60 peaks and we found that safrole was the most abundant compound, composing $87 \%$ of the oil. The oil was active against the promastigotes of Leishmania major, Leishmania mexicana, Leishmania braziliensis and Leishmania donovani with a favourable selectivity index against peritoneal macrophages from BALB/c mice. The Piper-oil inhibited the growing of intracellular amastigotes of L. donovani with an $I C_{50}$ value of $22.3 \pm 1.8 \mu \mathrm{g} / \mathrm{mL}$. This study demonstrates the usefulness of the essential oils as a promising alternative to treat leishmaniasis.

Key words: Leishmania - Piper auritum - essential oil

Leishmaniasis is caused by parasites of the Leishmania genus and affects more than 12 million people in 88 countries (Desjeux 2001). Antimonial derivatives are still the main compounds used for treatment, but they cause drug resistance in the parasite, severe toxicity in the patient and require parenteral administration. Second-line drugs, such as amphotericin B and pentamidine, are options in combined therapy or in cases of antimony treatment failures. In addition, clinical studies have identified the anticancer drug miltefosine as an effective antileishmanial agent. However, gastrointestinal toxicity and teratogenicity have been reported in association with this drug (Garnier \& Croft 2002, Davies et al. 2003). Therefore, the development of new antileishmanial compounds is imperative. Many people who live in endemic areas use plants as an alternative to treat the disease. Given that the present treatment situation is unsatisfactory, the study of plant-derived drugs for leishmaniasis treatment is highly needed (Brenzan et al. 2007).

Piper plants are considered an economically and ecologically important genus in the family Piperaceae and consist of about 1,000-2,000 species. Although the largest numbers of Piper species are found in the Americas (about 700 species) and Southern Asia (about 300 species), smaller numbers of species exist in the South Pacific (about 40 species) and Africa (about 15 species). Among them, Piper auritum Kunt is easily recognised by its large $(20-50 \mathrm{~cm})$ leaves, which are unequally lobed at the base and the very characteristic sarsaparilla or anise-like odour

+ Corresponding author: monzote@ipk.sld.cu

Received 5 August 2009

Accepted 5 February 2010 of its crushed leaves. These plants grow to about $6 \mathrm{~m}$ in height with a single main stem that often has small prop roots near the base. The large leaves are borne in two alternate ranks and are often held horizontally on upper branches forming a broad light-intercepting crown with relatively few large leaves (Berger 1983).

$P$. auritum has been used for a number of different culinary and medicinal purposes. Medicinal applications include uses as a sudorific, diuretic and stimulant in cases of fever, erysipelas, gout and angina, a local aesthetic, as treatment for gonorrhoea and colic, headache and wound poultice and as both a repulsive and a digestion stimulant (Joly 1981). Anti-inflammatory, antibacterial and antifungal activities have also been reported (Gupta et al. 1985, Hernández et al. 2003).

Studies in the literature have reported that Piper species have antileishmanial activity (Caio et al. 1999, Flores et al. 2007, Sarkar et al. 2008) and their essential oils have become an important target in the last few years in the search for new antiparasitic treatments (Antony et al. 2005). The aims of this study were to perform the chemistry characterisation of the essential oil from $P$. auritum and to evaluate its cytotoxicity and antileishmanial activity.

\section{MATERIALS AND METHODS}

Essential oil from P. auritum - P. auritum (Piperaceae) was collected in the Pharmacy and Foods Institute, Havana's University, Cuba, in July 2001. A voucher specimen (4622) is kept at the Experimental Station of Medicinal Plants Dr. Juan Tomás Roig, Cuba. The essential oil was obtained by distillation, under laboratory conditions, of the aerial parts of the plant using a Clevenger's apparatus according to the NR309 Regulation (Cuba 1992). The composition of the essential oil was further analysed by high resolution gas chromatography-mass spectrometry (HRGC-MS) using a QP5050-A 
Shimadzu DZU system equipped with flame ionisation detection $\left(280^{\circ} \mathrm{C}\right)$, a $30 \mathrm{~m}$ column, a $0.25 \mu \mathrm{m}$ film thickness and a $0.25 \mathrm{~mm}$ fused silica capillary column SPB-1. The flow rate was $1.5 \mathrm{~mL} / \mathrm{min}$, with a temperature program from $50^{\circ} \mathrm{C}$ at a rate $5^{\circ} \mathrm{C} / \mathrm{min}$ to $280^{\circ} \mathrm{C}$ for $30 \mathrm{~min}$ and the injection port was in split mode $1: 40$ at $280^{\circ} \mathrm{C}$. The mass spectrometer had an ionisation energy of 70 $\mathrm{eV}$ and an ion source at $280^{\circ} \mathrm{C}$.

Parasite culture - Strain MRHO/SU/59/P (LV39) of Leishmania major, MNYC/BZ/62/M379 of Leishmania mexicana, MHOM/BR/75/M2903 of Leishmania braziliensis and MHOM/ET/67/L82 of Leishmania donovani were maintained as promastigotes at $26^{\circ} \mathrm{C}$ in Schneider's medium (SIGMA, St. Louis, MO, USA) containing 10\% heat-inactivated foetal bovine serum (HFBS) (SIGMA, St. Louis, MO, USA), $100 \mu \mathrm{g}$ of streptomycin $/ \mathrm{mL}$ and $100 \mathrm{U}$ of penicillin/mL.

Laboratory animals - Female BALB/c mice, with a body weight of approximately 20-22 g, were obtained from The National Centre for Laboratory Animals Production (CENPALAB). The maintenance and care of mice were followed according to guidelines from the Ethical Committee for the Human Use of Laboratory Animals.

Reference drug - As a drug of reference, we used amphotericin B (IMEFA, Havan City, Cuba) at a concentration of $2 \mathrm{mg} / \mathrm{mL}$. The drug was diluted in sterile distilled water.

Antipromastigote activity - Eleven concentrations of the essential oil were assayed in quadruplicate. Exponentially growing cells $\left(10^{5}\right.$ promastigotes $/ \mathrm{mL}$ in $\left.199 \mu \mathrm{L}\right)$ were distributed in 96-well plates. One microlitre of essential oil dissolved in DMSO or $1 \mu \mathrm{L}$ of DMSO for control was added and then incubated at $26^{\circ} \mathrm{C}$ for $72 \mathrm{~h}$. After three days of exposure, the parasites were incubated at $37^{\circ} \mathrm{C}$ for $3 \mathrm{~h}$ with p-nitrophenyl phosphate $(20 \mathrm{mg} / \mathrm{mL})$ dissolved in $1 \mathrm{M}$ sodium acetate buffer (BDH, Poole, England) at $\mathrm{pH}$ 5.5, with $1 \%$ Triton X-100 (BDH, Poole, England). The absorbance was determined in an EMS Reader MF Version 2.4-0 at a wavelength of $405 \mathrm{~nm}$. The $50 \%$ inhibitory concentration $\left(\mathrm{IC}_{50}\right)$ was obtained from dose-response curves fit to data by means of the equation for the sigmoidal $\mathrm{E}_{\text {max }}$ model (Bodley et al. 1995).

Cytotoxicity assay - Resident macrophages were collected from peritoneal cavities of normal BALB/c mice in ice-cold RPMI 1640 medium (SIGMA, St. Louis, Mo, USA), supplemented with antibiotics, seeded at 30,000 cells/well and allowed to adhere for $2 \mathrm{~h}$ at $37^{\circ} \mathrm{C}$ in $5 \%$ $\mathrm{CO}_{2}$. After non-adherent cells were removed by washing with PBS, dilutions of the essential oil, in $1 \mu \mathrm{L}$ of DMSO, were added in $200 \mu \mathrm{L}$ of medium with $10 \%$ HFBS and antibiotics. The macrophages were treated with six concentrations of the product and cultures treated with $1 \mu \mathrm{L}$ of DMSO were included as controls. The cytotoxicity was determined after three days of incubation using the colorimetric assay with 3-[4,5-dimethylthiazol2-yl]-2,5-diphenyltetrazolium bromide (MTT) (SIGMA, St. Louis, MO, USA). MTT solutions were prepared at $5 \mathrm{mg} / \mathrm{mL}$ in PBS, filtered and sterilised at the time of use and $15 \mu \mathrm{L}$ of each solution were added to each well. Af- ter incubation for an additional $4 \mathrm{~h}$, the formazan crystals were dissolved by addition of $100 \mu \mathrm{L}$ of DMSO. The optical density was determined using an EMS Reader MF Version 2.4-0 at a test wavelength of $560 \mathrm{~nm}$ and a reference wavelength of $630 \mathrm{~nm}$ (Sladowski et al. 1993). The $50 \%$ cytotoxic concentration $\left(\mathrm{CC}_{50}\right)$ was obtained from dose-response curves fit to data by means of the equation for the sigmoidal $\mathrm{E}_{\max }$ model. Selectivity indices (SI) were then calculated by dividing the $\mathrm{CC}_{50}$ for peritoneal macrophages of BALB/c mice by the $\mathrm{IC}_{50}$ for Leishmania promastigotes (Tiuman et al. 2005).

Antiamastigote activity - Resident macrophages were collected from peritoneal cavities of normal BALB/c mice in ice-cold RPMI 1640 medium (SIGMA, St. Louis, Mo, USA) and supplemented with antibiotics. The peritoneal macrophages were plated at $10^{6}$ cells $/ \mathrm{mL}$ in $24-$ Well Lab-Tek plates (Costar ${ }^{\circledR}$, USA) and incubated for $2 \mathrm{~h}$ at $37^{\circ} \mathrm{C}$ under an atmosphere of $5 \% \mathrm{CO}_{2}$. Non-adherent cells were removed by washing with pre-warmed phosphate-buffered saline (PBS). Stationary-phase $L$. donovani promastigotes were added at a 10:1 parasite/ macrophage ratio and the cultures were incubated for another $24 \mathrm{~h}$. The cell monolayers were washed three times with pre-warmed PBS to remove free parasites and $999 \mu \mathrm{L}$ of RPMI completed medium and $1 \mu \mathrm{L}$ of the essential oil dissolved in DMSO, were added in duplicate and incubated for an additional $48 \mathrm{~h}$ (Espuelas et al. 2000). The cells and parasites were then fixed in absolute methanol, stained with Giemsa and examined under light microscopy. The number of intracellular amastigotes was determined by counting the amastigotes in 100 macrophages of each sample and the results were expressed as a percent of the reduction of the infection rate (\% IR) compared to that of the controls. The IRs were obtained by multiplying the percentage of infected macrophages by the number of amastigotes per infected macrophage. $\mathrm{The} \mathrm{IC}_{50}$ value was determined from the lineal concentration-response curves (Croft et al. 1996).

Statistical analysis - The data were analysed by outliers proof. The Mann-Whitney test was performed to find significance $(p<0.05)$ between the groups. The analysis was carried out with STATISTICA Programme for Windows, Version 4.5, 1993.

\section{RESULTS}

The HRGC-MS analysis of the essential oil revealed 60 peaks (Fig. 1). The retention times as well as some of the other characteristics of the 32 most important components are shown in Table I. The chromatogram demonstrated that safrole $(86.91 \%)$ was the most abundant compound in the essential oil (Fig. 2).

The essential oil, at concentrations lower than 100 $\mu \mathrm{g} / \mathrm{mL}$, decreased the viability of promastigotes after 72 $\mathrm{h}$ of incubation (Table II). The Piper-oil had a $\mathrm{CC}_{50}$ value of $106.4 \pm 3.4 \mu \mathrm{g} / \mathrm{mL}$ against peritoneal macrophages from $\mathrm{BALB} / \mathrm{c}$ mice and amphotericin $\mathrm{B}$ showed an $\mathrm{IC}_{50}$ value of $5.8 \pm 0.5 \mu \mathrm{g} / \mathrm{mL}$. Out of all of the species of Leishmania evaluated, the oil had the highest activity ( $\mathrm{p}$ $<0.05$ ) against $L$. donovani. 
The Piper-oil exhibited a concentration-dependent inhibitory effect against intracellular amastigotes of $L$. donovani (Fig. 3). The essential oil had an $\mathrm{IC}_{50}$ of 22.3 $\pm 1.8 \mu \mathrm{g} / \mathrm{mL}$ against amastigotes of $L$. donovani and the amphotericin B had an $\mathrm{IC}_{50}$ of $0.03 \pm 0.002 \mu \mathrm{g} / \mathrm{mL}$.

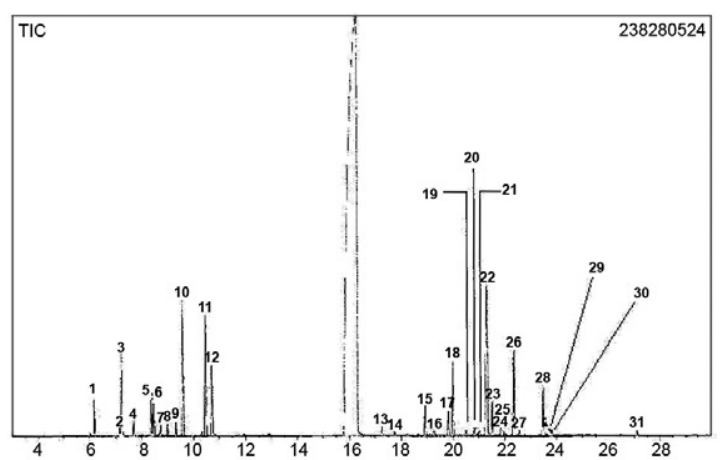

Fig. 1: chromatogram obtained by high resolution gas chromatography-mass spectrometry analysis of the essential oil from Piper auritum grown in Cuba.

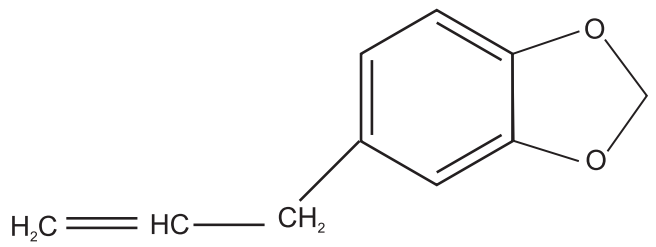

Fig. 2: chemical structure of safrol, main component of the essential oil from Piper auritum.

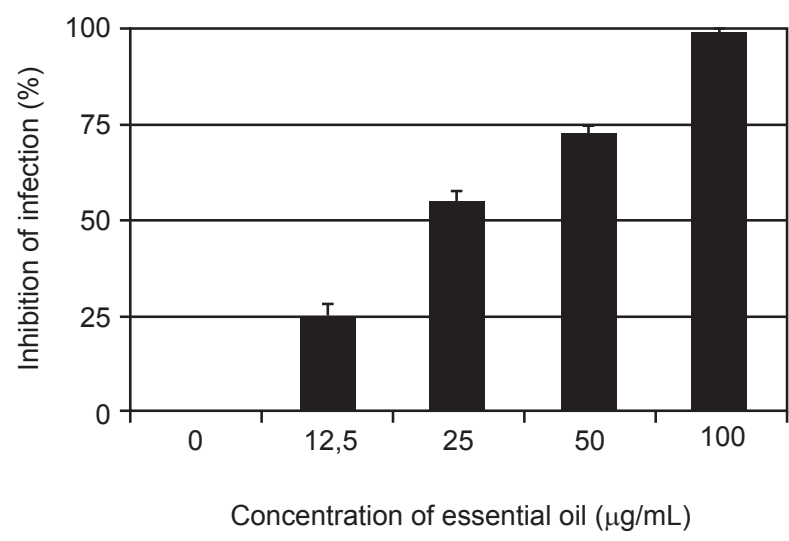

Fig. 3: effect of essential oil from Piper auritum on amastigote survival Leishmania donovani-infected mouse peritoneal macrophage. Results are from three experiments in duplicate and are shown as percentages \pm standard deviations. The control showed $7.6 \pm 1.8$ average of amastigote per macrophage and $86 \pm 6 \%$ of macrophage infected.

\section{DISCUSSION}

Piper species have been reported to have activity against Leishmania. For example, an ethanolic extract of leaves of Piper betle (Sarkar et al. 2008), the 2',6'-dihydroxy-4'-methoxychalcone isolated from the inflorescence of Piper aduncum (Caio et al. 1999) and kavapyron from leaves of Piper rusbyi (Flores et al. 2007) all showed in vitro activity against Leishmania. However, previous studies have reported that an aqueous and methanolic extract from the leaves of $P$. auritum did not show any activity against promastigotes of $L$. mexicana and L. braziliensis (Navarro et al. 2003). Although people commonly use infusion or beverages derived from herbs, there has been a resurgence of interest in essential oils, which are oily liquids obtained from plant material. Essential oils are a mixture of volatile aromatic compounds that have shown antimicrobial properties and have been used in pharmacology, phytopathology and food preservation (Bakkali et al. 2008). Furthermore, it has also been reported that various essential oils have inhibitory actions against diverse human parasites (Antony et al. 2005).

Recently, several essential oils extracted from plants have shown antileishmanial activity: Croton cajucara (Rosa et al. 2003), Ocimum gratissimum (UedaNakamura et al. 2006), Copaifera cearensis (Santos et al. 2008), Chenopodium ambrosioides (Monzote et al. 2006), Cymbopogon citratus and Lippia sidoides (Oliveira et al. 2009). These studies have demonstrated that essential oils can be a promising source of new antileishmanial drugs. In this view, we have been exploring the activity of essential oil from $P$. auritum against Leishmania parasites.

It is well known that the main component of $P$. auritum is safrole (Gupta et al. 1985, Hernández et al. 2003, García et al. 2007), which is an oxygenated monoterpene. In the essential oil studied here, this compound represented $86.9 \%$ and could be the major component responsible for the antileishmanial activity. We also found other components, such as monoterpenes and sesquiterpenes, which have been previously described in the literature (Vizoso et al. 1999, Hernández et al. 2003, García et al. 2007). In addition, safrole has been found in other plants and is the major component of the essential oil (85\%) of Sassafras albidum (Lauraceae) (Kamdem \& Gage 1995, Simić et al. 2004), which has shown antifungal activity (Simić et al. 2004).

There are no previous reports about the antileishmanial activity of Piper-oil. In our study, this essential oil inhibited the growth of promastigotes in all species of Leishmania used, with $\mathrm{IC}_{50}$ values between 12.8-63.3 $\mu \mathrm{g} / \mathrm{mL}$. In vitro studies show that amphotericin B is usually more active than the essential oil. However, the $\mathrm{IC}_{50}$ values described here for the essential oil are similar to those of commonly used antileishmanial drugs, such as pentostam and aminosidine, which showed an $\mathrm{IC}_{50}$ of 10,000 and $54 \mu \mathrm{g} / \mathrm{mL}$, respectively, against $L$. mexicana (Callahan et al. 1997). It is interesting to mention that, in our study, the essential oil was active against L. braziliensis, the main causal agent of mucocutaneous leishmaniasis, which has shown low sensitivity when treated 
TABLE I

Principal components of essential oil from Piper auritum obtained by high resolution gas chromatography-mass spectrometry analysis

\begin{tabular}{|c|c|c|c|c|c|}
\hline Peak & $t_{R}$ & Compound & $\mathrm{MM}$ & MF & $\%^{\mathrm{a}}$ \\
\hline 1 & 6.180 & $\begin{array}{c}\alpha \text {-pinene } \\
(4,7,7 \text {-trimethylbicyclo[3,1,1]-3-heptene) }\end{array}$ & 136 & $\mathrm{C}_{10} \mathrm{H}_{16}$ & 0.33 \\
\hline 2 & 7.150 & $\begin{array}{c}\quad+\text { sabinene } \\
\text { (1-methylene-4 } \alpha \text {-(2-propyl)-bicyclo[3,1,0]-hexene) }\end{array}$ & 136 & $\mathrm{C}_{10} \mathrm{H}_{16}$ & 0.07 \\
\hline 3 & 7.229 & $\begin{array}{c}\beta \text {-pinene } \\
\text { (4-methylene-7,7-dimethylbicyclo[3,1,1]-3-heptene) }\end{array}$ & 136 & $\mathrm{C}_{10} \mathrm{H}_{16}$ & 0.74 \\
\hline 4 & 7.691 & $\begin{array}{c}\text { Myrcene } \\
\text { (2-methyl-6-methylene-2,7-octadiene) }\end{array}$ & 136 & $\mathrm{C}_{10} \mathrm{H}_{16}$ & 0.13 \\
\hline 5 & 8.375 & $\begin{array}{c}\alpha \text {-terpinene } \\
\text { (1-methyl-4-[2-propyl]-cyclohexa-1,4-diene) }\end{array}$ & 136 & $\mathrm{C}_{10} \mathrm{H}_{16}$ & 0,36 \\
\hline 6 & 8.463 & $\begin{array}{c}\text { p-cymene } \\
\text { (1-methyl-4-[2-propyl]-bencene) }\end{array}$ & 134 & $\mathrm{C}_{10} \mathrm{H}_{14}$ & 0.30 \\
\hline 7 & 8.731 & $\begin{array}{c}\text { Limonene } \\
\text { (1-methyl-4-[2-propenyl]-cyclohex-1-ene) }\end{array}$ & 136 & $\mathrm{C}_{10} \mathrm{H}_{16}$ & 0.09 \\
\hline 8 & 8.996 & $\begin{array}{c}\beta \text {-ocimene } \\
\text { (2,6-dimethyl-2E,5Z,7-octanotriene) }\end{array}$ & 136 & $\mathrm{C}_{10} \mathrm{H}_{16}$ & 0.11 \\
\hline 9 & 9.311 & $\begin{array}{c}\alpha \text {-ocimene } \\
\text { (2,6-dimethyl-2Z,5Z,7-octanotriene) }\end{array}$ & 136 & $\mathrm{C}_{10} \mathrm{H}_{16}$ & 0.13 \\
\hline 10 & 9.594 & $\begin{array}{c}\gamma \text {-terpinene } \\
\text { (1-methyl-4-[2-propyl]-1,4-cyclohexadiene) }\end{array}$ & 136 & $\mathrm{C}_{10} \mathrm{H}_{16}$ & 1.32 \\
\hline 11 & 10.469 & $\begin{array}{c}\text { Terpinolene } \\
\text { (1-methyl-4-propylidene-1-cyclohexene) }\end{array}$ & 136 & $\mathrm{C}_{10} \mathrm{H}_{16}$ & 1.11 \\
\hline 12 & 10.707 & $\begin{array}{c}\text { 1-linalool } \\
\text { (2,6-dimethyl-6-hydroxy-2,7-octadiene) }\end{array}$ & 154 & $\mathrm{C}_{10} \mathrm{H}_{18} \mathrm{O}$ & 0.66 \\
\hline MP & 16.000 & $\begin{array}{c}\text { Safrole } \\
\text { (1,2-methylenedioxy-4-[1-(2-propenyl)]-bencene) }\end{array}$ & 163 & $\mathrm{C}_{10} \mathrm{H}_{11} \mathrm{O}_{2}$ & 86.91 \\
\hline 13 & 17.262 & Methyl decanoate & 186 & $\mathrm{C}_{11} \mathrm{H}_{22} \mathrm{O}_{2}$ & 0.08 \\
\hline 14 & 17.750 & $\begin{array}{c}\text { Eugenol } \\
\text { (1-hydroxy-2-methoxy-4-[1-(2-propenyl)]bencene) }\end{array}$ & 164 & $\mathrm{C}_{10} \mathrm{H}_{22} \mathrm{O}_{2}$ & 0.04 \\
\hline 15 & 18.931 & $\alpha$-copaene & 204 & $\mathrm{C}_{15} \mathrm{H}_{24}$ & 0.28 \\
\hline 16 & 19.280 & $\beta$-elemene & 204 & $\mathrm{C}_{11} \mathrm{H}_{22} \mathrm{O}_{2}$ & 0.08 \\
\hline 17 & 19.824 & Methyl 2,4-decadienoate & 182 & $\mathrm{C}_{11} \mathrm{H}_{18} \mathrm{O}_{2}$ & 0.23 \\
\hline 18 & 20.004 & Trans-caryophyllene & 204 & $\mathrm{C}_{15} \mathrm{H}_{24}$ & 0.75 \\
\hline 19 & 20.512 & Z3,Z6,E8-dodecatrien-1-ol & 180 & $\mathrm{C}_{11} \mathrm{H}_{18} \mathrm{O}_{2}$ & 0.49 \\
\hline 20 & 20.838 & $\alpha$-humulene & 204 & $\mathrm{C}_{11} \mathrm{H}_{18} \mathrm{O}_{2}$ & 0.09 \\
\hline 21 & 21.033 & Methyl Z3,Z6,E8-dodecatrienoate & 208 & $\mathrm{C}_{11} \mathrm{H}_{18} \mathrm{O}_{2}$ & 0.49 \\
\hline 23 & 21.525 & Germacrene & 204 & $\mathrm{C}_{11} \mathrm{H}_{18} \mathrm{O}_{2}$ & 0.37 \\
\hline 24 & 21.858 & Aromadendrene & 204 & $\mathrm{C}_{11} \mathrm{H}_{18} \mathrm{O}_{2}$ & 0.68 \\
\hline 25 & 21.917 & Myristicine & 192 & $\mathrm{C}_{11} \mathrm{H}_{18} \mathrm{O}_{2}$ & 1.59 \\
\hline 26 & 22.366 & Tetradecane & 204 & $\mathrm{C}_{15} \mathrm{H}_{24}$ & 0.93 \\
\hline 27 & 22.560 & $\delta$-cadinene & 204 & $\mathrm{C}_{15} \mathrm{H}_{24}$ & 0.05 \\
\hline 28 & 23.479 & $\begin{array}{c}\text { Nerolidol } \\
\text { (10-hydroxy-2,6,10-trimethyl-2,6,11-dodecatriene) }\end{array}$ & 222 & $\mathrm{C}_{15} \mathrm{H}_{16} \mathrm{O}$ & 0.55 \\
\hline 29 & 23.811 & Caryophyllene oxide & 220 & $\mathrm{C}_{15} \mathrm{H}_{24} \mathrm{O}$ & 0.07 \\
\hline 30 & 27.115 & Heptadecane & 240 & $\mathrm{C}_{17} \mathrm{H}_{36}$ & 0.05 \\
\hline
\end{tabular}

the related compounds are the $99.08 \%$ of the essential oil. $a$ : \% from total area; MF: molecular formule; MM: molecular mass; MP: main pick; $\mathrm{t}_{\mathrm{R}}$ : retention time. 
TABLE II

Effect of the essential oil from Piper auritum on promastigotes of Leishmania spp and corresponding selectivity index

Essential oil from Piper auritum

Amphotericin B

\begin{tabular}{|c|c|c|c|c|}
\hline \multirow[b]{2}{*}{ Species } & \\
\hline & $\mathrm{IC}_{50} \pm \mathrm{SD}(\mu \mathrm{g} / \mathrm{mL})^{a}$ & $\mathrm{SI}^{b}$ & $\mathrm{IC}_{50} \pm \mathrm{SD}(\mu \mathrm{g} / \mathrm{mL})$ & SI \\
\hline Leishmania major & $29.1 \pm 1.4^{c}$ & 4 & $0.022 \pm 0.001$ & 264 \\
\hline Leishmania mexicana & $63.3 \pm 2.6$ & 2 & $0.0135 \pm 0.002$ & 430 \\
\hline Leishmania braziliensis & $52.1 \pm 3.1$ & 2 & $0.035 \pm 0.004$ & 166 \\
\hline Leishmania donovani & $12.8 \pm 2.8^{d}$ & 8 & $0.03 \pm 0.003$ & 193 \\
\hline
\end{tabular}

$a$ : concentration of drug that caused $50 \%$ of inhibitory growth of promastigotes; $b$ : selectivity index: $\mathrm{CC}_{50}$ against macrophage/ $\mathrm{IC}_{50}$ against promastigotes. The $\mathrm{CC}_{50}$ against macrophage of the essential oil from $P$. auritum and amphotericin $\mathrm{B}$ were of 106.4 and $5.8 \mu \mathrm{g} / \mathrm{mL}$, respectively; $c$ : significant differences $(\mathrm{p}<0.05)$ compared with the $\mathrm{IC}_{50}$ values of essential oil against Leishmania mexicana and Leishmania braziliensis, using the Mann-Whitney test; $d$ : significant differences $(\mathrm{p}<0.05)$ compared with the other groups, using the Mann-Whitney test.

with derivatives of antimonies (Bailey \& Lockwood 2007) and miltefosine (Yardley et al. 2005). Additionally, the essential oil is a complex mixture of substances and the purification of active compounds might result in a considerable increase of their antileishmanial activity. Amphotericin B is a pure compound and constitutes the most active antileishmanial drugs. Nevertheless, the toxicity of amphotericin B makes it a second-option treatment behind antimony in areas of refractory leishmaniasis (Garnier \& Croft 2002, Guerin et al. 2002). Piper-oil was more active against promastigotes of $L$. chagasi $\left(\mathrm{IC}_{50}<63 \mu \mathrm{g} / \mathrm{mL}\right)$ than other essential oils recently studied, such as $O$. gratissimum $\left(\mathrm{IC}_{50}=75 \mu \mathrm{g} / \mathrm{mL}\right)$ and $L$. sidoides $\left(\mathrm{IC}_{50}=89 \mu \mathrm{g} / \mathrm{mL}\right.$ ) (Oliveira et al. 2009).

In parallel, different activities were observed between the species of Leishmania and consequently with their SIs. Several differences in the susceptibility of Leishmania strains have been described and are dependent upon the species of parasite (Croft et al. 2002). In this study, the oil showed a better SI against $L$. donovani, which is the causal agent of visceral leishmaniasis. L. donovani is the fatal form of the disease and causes about 500,000 deaths per year if left untreated (Guerin et al. 2002). For this reason, further pharmacological studies in animal models of visceral leishmaniasis should be performed.

Piper-oil inhibited the growth of intracellular amastigotes of $L$. donovani at non-toxic concentrations, with values lower than those reported for meglumine antimoniate $\left(\mathrm{IC}_{50}\right.$ $=80 \mu \mathrm{g} / \mathrm{mL}$ ), which is a drug of first line use (Ephros et al. 1999). It was also more effective than other natural products such as the hydroalcoholic extract from Austroplenckia populnea $\left(\mathrm{IC}_{50}=52 \mu \mathrm{g} / \mathrm{mL}\right.$ ) (Andrade et al. 2008).

Plants are an important source in the search for new and selective agents for the treatment of tropical diseases caused by protozoan. In conclusion, this study is a part of a continuing search for new drugs (with high activity and low side effects) to treat protozoa parasites, such as Leishmania, and demonstrates the usefulness of the essential oils as a promising alternative. Further evaluation of the essential oil from $P$. auritum against visceral murine leishmaniasis will be performed.

\section{REFERENCES}

Andrade SF, da Silva FAA, de O'Resende D, Silva ML, Cunha WR, Nanayakkara NP, Bastos JK 2008. Antileishmanial, antimalarial and antimicrobial activities of the extract and isolated compounds from Austroplenckia populnea (Celastraceae). Z Naturforsch C 63: 497-502.

Antony JP, Fyfe L, Smith H 2005. Plant active components - a resource for antiparasitic agents? Trends Parasitol 21: 462-468.

Bailey MS, Lockwood DNJ 2007. Cutaneous leishmaniasis. Clin Dermatol 25: 203-211.

Bakkali F, Averbeck S, Averbeck D, Idaomar M 2008. Biological effects of essential oils - a review. Food Chem Toxicol 46: 446-475.

Berger WC 1983. Piper auritum. In DH Janzen, Natural history of Costa Rica, University of Chicago Press, Chicago, p. 304-305.

Bodley AL, McGarry MW, Shapiro TA 1995. Drug cytotoxicity assay for African trypanosomes and Leishmania species. J Infect Dis 172: 1157-1159.

Brenzan MA, Nakamura CV, Dias Filho, BP, Ueda-Nakamura T, Young MCM, Cortez DAG 2007. Antileishmanial activity of crude extract and coumarin from Calophyllum brasiliense leaves against Leishmania amazonensis. Parasitol Res 101: 715-722.

Caio TSE, Lima MD, Kaplan MAC, Nazareth MM, Rossi-Bergmann B 1999. Selective effect of 2',6'-dihydroxy-4'methoxychalcone isolated from Piper aduncum on Leishmania amazonensis. Antimicrob Agents Chemother 43: 1234-1241.

Callahan HL, Portal AC, Devereaux R, Grogl M 1997. An anexic amastigote system for drug screening. Antimicrob Agents Chemother 41: 818-822.

Croft SL, Snowdon D, Yardley V 1996. The activities of four anticancer alkyllysophospholipids against $L$. donovani, Trypanosoma cruzi and Trypanosoma brucei. J Antimicrob Chemother 38: 1041-1047.

Croft SL, Yardley V, Kendrick H 2002. Drug sensitivity of Leishmania species: some unresolved problems. Trans $R$ Soc Trop Med Hyg 96: 127-129.

Cuba - Ministerio de Salud Pública 1992. Norma Ramal SP 309. Medicamentos de origen vegetal: droga cruda. Métodos de ensayos, MINSAP, La Habana, 16-29 pp. 
Davies CR, Kaye P, Croft SL, Sundar S 2003. Leishmaniasis: new approach to disease control. Br Med J 15: 377-382.

Desjeux P 2001. The increased in risk factors for leishmaniasis worldwide. Trans R Soc Trop Med Hyg 95: 239-243.

Ephros M, Bitnun A, Shaked P, Walkman E, Zilberstein D 1999. Stage-specific activity of pentavalent antimony against Leishmania donovani axenic amastigotes. Antimicrob Agent Chemother 43: $278-282$

Espuelas S, Legrand P, Loiseau PM, Bories C, Barratt G, Irache JM 2000. In vitro reversion of amphotericin B resistance in Leishmania donovani by poloxamer 188. Antimicrob Agents Chemother 44: 2190-2192.

Flores N, Cabrera G, Jiménez IA, Pinero J, Jiménez A, Bourdy G, Cortes-Selva F, Bazzocchi IL 2007. Leishmanicidal constituents from the leaves of Piper rusbyi. Planta Med 73: 206-211.

García A, Leyva M, Martínez JR, Stashenko EE 2007. Determinación de la composición química y actividad antioxidante in vitro del aceite esencial de Piper auritum Kunth (Piperaceae) difundida en la costa colombiana. Scientia Tech 33: 439-442.

Garnier T, Croft SL 2002. Topical treatment for cutaneous leishmaniasis. Curr Opin Invest Drugs 3: 538-544.

Guerin PJ, Olliaro P, Sundar S, Boelvaert M, Croft SL, Desjeux P 2002. Visceral leishmaniasis: current status of control, diagnosis and treatment and proposed research and development agenda. Lancet Infect Dis 2: 494-501.

Gupta MP, Arjas TD, Williams NH, Bos R, Tattje DHE 1985. Safrole, the main component of the essential oil from Piper auritum Panamá. J Nat Prod 48: 330-336.

Hernández L, Rodríguez M, García D, Pino J 2003. Actividad antidermatofítica in vitro de aceites esenciales. Available from: http://scielo.sld. cu/scielo.php?script=sci_arttext\&pid=S1028-47962003000200004\&lng=es\&nrm=iso\&tlng=es.

Joly LG 1981. Feeding and trapping fish with Piper auritum. Economic Bot 35: 383-390.

Kamdem DP, Gage DA 1995. Chemical composition of essential oil from the root bark of Sassafras albidum. Planta Med 61: 574-575.

Monzote L, Montalvo AM, Almanonni S, Scull R, Miranda M, Abreu J 2006. Activity of the essential oil from Chenopodium ambrosioides grown in Cuba against Leishmania amazonensis. Chemother 52: 130-136.
Navarro MC, Montilla MP, Cabo MM, Galisteo M, Cáceres A, Morales C, Berger I 2003. Antibacterial, antiprotozoal and antioxidant activity of five plants used in Izabal for infectious diseases. Phytother Res 17: 325-329.

Oliveira VCS, Moura DMS, Lopes JAD, de Andrade PP, da Silva NH, Figueiredo RCBQ 2009. Effects of essential oils from Cymbopogon citratus (DC) Stapf., Lippia sidoides Cham., and Ocimum gratissimum L. on growth and ultrastructure of Leishmania chagasi promastigotes. Parasitol Res 104: 1053-1059.

Rosa MSS, Mendonça-Filho RR, Bizzo HR, Rodrigues IA, Soares RMA, Souto-Padrón T, Alviano CS, Lopes AHCS 2003. Antileishmanial activity of a linalool-rich essential oil from Croton cajucara. Antimicrob Agents Chemother 47: 1895-1901.

Santos AO, Ueda-Nakamura T, Dias BP, Veiga VF, Pinto AC, Nakamura CV 2008. Effect of Brazilian copaiba oils on Leishmania amazonensis. J Ethnopharmacol 120: 204-208.

Sarkar A, Sen R, Saha P, Ganguly S, Mandal G, Chatterjee M 2008. An ethanolic extract of leaves of Piper betle (Paan) Linn mediates its antileishmanial activity via apoptosis. Parasitol Res 102: 1249-1255.

Simić A, Soković MD, Ristić M, Grujić-Jovanović S, Vukojević J, Marin PD 2004. The chemical composition of some Lauraceae essential oils and their antifungal activities. Phytother Res 18: 713-717.

Sladowski D, Steer SJ, Clothier RH, Balls M 1993. An improve MTT assay. J Immunol Methods 157: 203-207.

Tiuman TS, Ueda-Nakamura T, Cortez DAG, Dias Filho BP, MorgadoDíaz JA, de Souza W, Nakamura CV 2005. Antileishmanial activity of parthenolide, a sesquiterpene lactone isolated from Tanacetum parthenium. Antimicrob Agent Chemother 49: 176-182.

Ueda-Nakamura T, Mendonça-Filho RR, Morgado-Díaz JA, Maza PK, Dias Filho BP, Cortez DAG, Alviano DS, Rosa MSS, Lopes AHCS, Alviano CS, Nakamura CV 2006. Antileishmanial activity of Eugenol-rich essential oil from Ocimum gratissimum. Parasitol Int 55: 99-105.

Vizoso A, García A, Ramos A 1999. Ausencia de potencial genotóxico in vitro e in vivo de un extracto fluido de Piper auritum H.K.B. Rev Cub Plant Med 3: 57-64.

Yardley V, Croft SL, De Doncker S, Dujardin JC, Koirala S, Rijal S, Miranda C, Llanos-Cuentas A, Chappuis F 2005. The sensitivity of clinical isolates of Leishmania from Peru and Nepal to miltefosine. Am J Trop Med Hyg 73: 272-275. 